\title{
ELAINE TEDESCO
}

\section{「I}

Os panoramas e as montagens

fotográficas de Matta-Clark

\section{RESUMO}

No presente ensaio o surgimento dos panoramas no final dos setecentos e sua relação com a pintura de paisagens urbanas, especialmente as realizadas pelo veneziano Canaletto, são trazidos ao texto para introduzir a relação entre a criação de um panorama e o ponto de vista de quem o cria. Explora-se o conceito falso panorama desenvolvido por Pepa López Poquet relacionado com as montagens fotográficas realizadas por Gordon Matta-Clark a partir de suas interferências em edificações em espaços urbanos.

\section{PALAVRAS-CHAVE}

Panoramas; Falsos Panoramas; Gordon MattaClark. 


\title{
OS PANORAMAS E AS MONTAGENS FOTOGRÁFICAS DE MATTA-CLARK
}

\author{
I
}

Antonio Canal conhecido como Canaletto criou, durante a primeira metade dos setecentos, uma série de pinturas da paisagem urbana Veneziana. Em cada tela o artista apresenta um enquadramento visto a partir de um local diferente da cidade. Nessas imagens a presença da arquitetura é preponderante - os diferentes estilos; aparência das superfícies; presença da forma; riqueza e decadência revelam a passagem do tempo, nelas as pessoas e seus afazeres complementam as cenas. A assimetria e a amplitude de seus horizontes; o contraste entre a solidez da arquitetura e ainda a efemeridade das situações cotidianas sugerem que $o$ artista tenha elaborado tais composições levando em conta o movimento de seu olhar de um lado a outro diante dos locais retratados. Esses enquadramentos abertos lateralmente, além do ângulo de $60^{\circ}$ remetem aos atuais enquadramentos propiciados pelo uso de lentes grande-angular ou pela montagem eletrônica de fotografias criando panoramas.

Se fosse possível vê-las em um grande conjunto, isso possibilitaria ao observador uma visão panorâmica da cidade criada por um artista que a habitava e logo estava em constante deslocamento por suas ruelas e canais, o que o habilitava a escolher os melhores pontos de vista para poder construir uma visão complexa da cidade de Veneza.

II

O primeiro panorama $360^{\circ}$ foi construído por Robert Barker (contemporâneo de Canaletto) em Edimburgo, 1787, mas foi apenas no século XIX que essa forma de apresentar a paisagem foi largamente explorada na Europa. Segundo François Robinchon a invenção foi importada à França por meio do engenheiro Robert Fulton em 1799 que a batizou de panorama ou tela circular e sem bordas. Segundo Robinchon "Os panoramas não são outra coisa que uma maneira de expor uma grande tela, de forma que o olhar do espectador, que tem o seu horizonte completamente abarcado, não encontra os limites do que é a tela, e assim ele experimenta a mais completa ilusão".

\section{III}

Para Walter Benjamin a multiplicação dos panoramas tem seu ponto culminante no ROBINCON, 1985, p. 65-86. momento de aparição das primeiras passagens em Paris (os I 5 anos que se seguem após 
1822), época da crescente utilização do ferro na arquitetura e na qual também se desenvolve o que o autor nomeia de panorama literário, um tipo de literatura que obedece o princípio de primeiro plano e plano de fundo dos panoramas. ${ }^{2} \mathrm{O}$ autor vê todas essas manifestações: literária, arquitetônica e plástica interligadas ao flaneur.

Benjamin afirma "Por mil artifícios técnicos, aventura-se infatigavelmente a fazer dos lugares escolhidos à perfeita imitação da natureza. Ao recorrer à ilusão por reproduzir fielmente as mudanças naturais, os panoramas anunciam, além da fotografia, o cinema e o filme sonoro". ${ }^{3}$

Os panoramas aos quais Benjamin se refere eram pinturas de paisagens da cidade que se apresentavam em um espaço fechado formando um círculo de $360^{\circ}$ e que sob o efeito de luzes revelavam pouco a pouco o horizonte ao espectador situado no centro da sala em um platô, dando-lhe a impressão de estar no alto de uma montanha. $O$ espaço fechado e escuro propunha ao espectador a imersão e o movimento para ver as cenas iluminadas.

\section{IV}

Atualmente algumas câmeras fotográficas digitais já possuem em seu menu a opção panoramas e, na web, não é difícil encontrar sites especializados em proporcionar a montagem eletrônica de panoramas. Nesse jogo com os efeitos da tecnologia, disponíveis nos programas das "caixas-pretas" 4 digitais, as estruturas estéticas mantêm-se fiéis aos enquadramentos regulares e horizontais dos primeiros panoramas. Para obtenção fotográfica dessas paisagens a boa técnica recomenda o uso de um tripé a fim de manter os deslocamentos da câmera em uma mesma continuidade horizontal. Apesar do movimento para obtenção desta visão panorâmica ser circular, gira-se com a câmera em um ponto fixo, depois as imagens são montadas lateralmente criando a impressão de um horizonte contínuo. Os panoramas são apresentados em uma linha horizontal contínua, na qual a paisagem se abre ou em programas eletrônicos nos quais é possível acompanhar o movimento da paisagem.

Os panoramas atuais ainda sugerem um olhar de $360^{\circ}$ ao redor do corpo em direção ao seu entorno, mas a forma como são expostos ao espectador mudou muito. $O$ cinema $360^{\circ}$ que seria o seu sucessor mais direto praticamente não existe, ficou datado nos anos 70. Entretanto, os panoramas assumiram através da fotografia e da eletrônica novas características. A tela contendo a paisagem é mais pintada, deixou de ser uma superfície material e passou para outros suportes como: a impressão fotográfica, a tela do computador, ou desloca-se ao espaço através dos projetores. A escala da tela de apresentação deixou de ser arquitetônica para tornar-se objectual. Com essa mudança o modo de visualização e o comportamento dos que assistem a um panorama também assume novas características. $\mathrm{O}$ acesso a algum dos infinitos sites de panoramas de paisagens, locais turísticos e exóticos e panoramas interativos disponíveis na Internet é

BENJAMIN, 2000, p. 50.

Idem, $\mathrm{p} 49$.

FLUSSER, 2002, p. 28. 


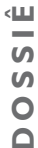

Pepa Lopez é artista plástica com trabalhos nas áreas de pintura, instalação e filme é também professora junto a Universidade Politécnica de Valência onde participa do grupo de pesquisa Laboratorio de Luz. Uma exploração didática desta pesquisa foi proposta por Pepa Lopez e Trinidad Garcia na oficina "Falso Panorama / Experiencias de Multivisión en Vídeo Digital. Prácticas y Resultados" apresentada no congresso: "Conferencia Internacional de Arte Eletrónica e Dixital ( $3^{\circ}$. 2006. Pontevedra)". IN: ACTAS Congresso Internacional ARTECH, 2006, "Conectando Fronteiras: arte, tecnoloxia, ciencia, sociedade", Pazo da Cultura, Pontevedra, 17 e 18 de novembro de 2006. Vigo: Universidade de Vigo, 2006.p. 175 - 178. A pesquisa será apresentada no congresso Internacional "Los Enséniarios de Bellas Artes en el Espacio Europeo de Educación Superior", Universidad Politecnica de Valencia, Facultad de BBAA, II-I3 de Deciembre, 2007. ver: www.bbaa.upv.es/cotad/congres/cla 2007.html.

FRIEDMAN, 2000, p. 36. geralmente realizado em um local fechado - em casa ou em um espaço público. De qualquer modo quem acessa um site de panorama pela internet provavelmente está sentado, apertando teclas e manuseando um mouse com os olhos dirigidos para a tela.

Não há um deslocamento físico do sujeito acompanhando as cenas da paisagem que vão sendo iluminadas, como faziam os apreciadores de panoramas no século XIX, é antes o panorama que se movimenta diante do espectador.

\section{Os falsos panoramas}

A artista Pepa Lopez vem a alguns anos desenvolvendo uma investigação sobre o conceito panorama, que desde 2003 foi transposta a sua docência universitária na UPV. ${ }^{5}$ Ao longo desse processo de pesquisa no qual observou em pinturas e fotografias as ampliações do campo do olhar e suas formas de representação e apresentação, Lopez formulou o conceito falso panorama. Portanto destaca-se que é um conceito decorrente da análise de determinadas convergências estruturais existentes em montagens fotográficas realizadas por artistas contemporâneos. Em um falso panorama identificamse diferentes pontos de vista do sujeito sobre o ambiente. Constata-se o registro e a tradução de momentos perceptivos incluindo o tempo e os deslocamentos no espaço através da exploração do princípio da montagem. São montagens fotográficas nas quais os artistas pretendem expandir os limites do enquadramento fotográfico. Essa expansão, no caso dos falsos panoramas, não está restrita as idéias de horizontalidade e continuidade espacial e temporal como nos primeiros panoramas.

\section{VI}

\section{Matta-Clark e o panorama urbano}

Olhando atentamente algumas das montagens fotográficas apresentadas na exposição de Gordon Matta-Clark no Reina Sofia em Madri, 2006, pensei que tais montagens poderiam ser analisadas a partir do conceito proposto por Lopez.

Gordon Matta-Clark filho do pintor tardo surrealista Roberto Matta e Ane Clark irmão gêmeo de Batan formou-se arquiteto pela Escola de Arquitetura da Universidade de Cornell, Ithaca, New York. Em I 97I fundou junto com a bailarina Caroline Goodem e outros 3 membros do grupo Anarquitetura o Food - restaurante e centro de encontros de artistas no Soho na mesma cidade.
Segundo Malsh Friedman:
Sus primeras obras no dan en principio testimonio de su confrontación con la arquitectura. Más bien parece haberle influido de forma duradera la discusión en torno a Marcel Duchamp tras su muerte. En ello ocupa un lugar central la transformación de materiales en otras substancias. Como muestran las obras de 1969-70.6 
A contextualização do lugar é um aspecto fundamental na obra de Matta-Clark. Quando o artista passa a operar sobre os edifícios abandonados em New York tratandoos a través do princípio de subtração está posicionando-se criticamente em relação a arquitetura e urbanização de seu país, especificamente da cidade onde vivia. Essa contextualização está imbricada com a vida cotidiana, Christo afirma que Matta-Clark:

\begin{abstract}
Estaba interesado en las formas no sólo de un modo abstracto, sino también en comprar, alquilar, coger, usar, poseer, cortar un lugar; todo eso revivía el espacio... Su obra está íntimamente relacionada con la arquitectura... Demolición y cambio - es algo muy excitante porque se hace por gente y maquinaria pesada... Cuando Gordon cotaba un edificio, o necesitaba ayuda para hacer un proyecto muy grande, era porque necesitaba acabar el trabajo. Tenía una relación muy fuerte con la materialidad de lo real, un entendimiento de la planta y de la proporción, espacio transitable... arquitectura real. ${ }^{7}$
\end{abstract}

Durante o processo de intervenções sobre prédios abandonados o artista desenvolvia simultaneamente uma série de registros (fotografias e filmes) das modificações provocadas. Esses desdobramentos não eram meros documentos. Há no uso de cada meio uma outra espécie de exploração dos lugares. Gordon Matta-Clark queria que o "enquadramento fotográfico fosse assim como os prédios - violável". Ao elaborar as primeiras montagens o artista estava interessado em captar a experiência completa da peça. "São aproximações a esta maneira ambulante de ir-se sabendo o que há no espaço. Basicamente são caminhos para atravessar o espaço". ${ }^{8}$

Seria redutor afirmar que os trabalhos anarquitetônico-fotográfico-filmicos de Matta-Clark são panoramas ou falsos panoramas, porém, no contexto do presente projeto de pesquisa, quer-se pensar que suas montagens fotográficas relacionam-se criticamente com a idéia de um panorama urbano. Essas montagens podem perfeitamente ser vistas como um Falso panorama se observadas através do conceito formulado por Lopez e a partir daí tem muito a contribuir para a atualização da linguagem dos panoramas contemporâneos, sejam impressos ou eletrônicos.

Mas também se deve considerar os seus registros e montagens fotográficas como desdobramentos de um processo mais amplo, que não está encerrado em nenhuma relação entre fotografias. Olhando-se em direção as suas investigações como buscas de ruptura e expansão dos limites da arquitetura moderna, infere-se que Matta-Clark constrói uma série de panoramas urbanos que rompem os limites das camadas constitutivas das edificações. Como voyeur ele quer ver através das camadas de paredes construídas nas edificações que lhe cercam. Ver de uma sala a outra, de um andar a outro, da rua a casa e vice e versa. 


Respondendo uma pergunta de Judith Russi em fevereiro de 1978 no MAC-Chicago
sobre as suas fotografias serem ou não meros documentos Matta-Clark afirmou:
No. Pienso que el arte narrativo ha arruinado para mí un cierto tipo de
mezclas de palabras e imágenes. Pero creo que es posible ver el
mérito de grupos de imágenes fotográficas, interceptable muy
personalmente, que procuran interceptar, como en este caso, una
situación espacial. Tamben podríamos llamarlo una suerte de espacio
psicológico. Y en la manera que Yo interpreto la pieza, tal como hago
ahora, he llegado de una documentación completa, en el sentido de
documentación instantánea, a un ahondamiento real en este tipo de
documentación tiempo-evolución de la obra, y luego, más allá, una
especie de tiempo y movimiento que lleva a experimentar la obra, y
más allá, lo que pasa a la gente en la obra. El camino era de la
instantánea a una especie de sistema de documentación, a una especie
de sistema personal de documentación, a una especie de interpretación
"voyeurística"y, finalmente, al interior de una especie de cosa narrativa
que está sujeto a toda clase de variaciones.

A ação de romper é articulada por Matta-Clark tanto nas intervenções sobre a arquitetura quanto nas obtenções e posteriores montagens fotográficas.

Para ver e analisar as diferentes montagens fotográficas de $A$ W-Hole House: datun cut, core cut, trace coeur, 1973; Oficina Barroca, 1974 e Conical intersect, 1975 pela perspectiva do conceito panorama ou seu desdobramento como falso panorama é necessário operar junto à noção de panorama os conceitos como: gesto, ruptura, corte e deslocamento. Romper com a horizontalidade e com a continuidade. Cada uma das montagens de Oficina Barroca condensa, guarda e justapõe uma série de movimentos e de relações corpo, câmera, espaço. São grupos de 2,3,5 e 8 fotografias que através da montagem indicam uma ruptura espacial. Sugerem o deslocamento do corpo pelo espaço. São explícitos os diferentes movimentos de câmera = para cima, para baixo, esquerda, direita, para frete, para trás e através dos diferentes andares e salas. É através dessas rupturas que se revelam as estruturas. As rupturas apresentam-se como passagens para o olhar. Para o artista a fotografia era um verdadeiro material ${ }^{10}$ sujeito a toda espécie de transformações e manipulações.

Matta-Clark não está em um ponto fixo girando em torno de si mesmo e vendo ao Idem, p. 332 . seu redor. Suas montagens oferecem subsídios para ampliar nosso campo de visão ao mesmo tempo em que apresentam um panorama urbano de sua época. Suas incisões e desconstruções explodem as camadas entre os espaços e revelam o modus constitutivo ROUILLÉ, 2005. de cada (prédios, edifícios, e casas) construção. Suas explorações são ancoradas em 
limites estruturais ao mesmo tempo em que vislumbram uma outra arquitetura, um outro panorama urbano.

\section{REFERÊNCIAS}

BENJAMIN, Walter. "Paris, Capitale du XIX e siècle. "II - Daguerre ou les Panoramas. IN: OEUVRES III. Paris: Éditions Gallimard, 2000.

CHRISTO, Catálogo Matta-Clark - A retrospective, Chicago, 1985.

FLUSSER, Vilém. Filosofia da Caixa Preta. São Paulo: Relume Dumará, 2002.

FRIEDMAN, Malsh. Gordon Matta-Clark. IN: CORBEIRA, Dario, ¿Construir...o desconstruir? Textos sobre Gordon Matta-Clark. Salamanca: Ediciones Universidad de Salamanca, 2000.

LOPEZ, Pepa; GARCIA, Trinidad. Falso Panorama / Experiencias de Multivisión en Vídeo Digital. Prácticas y Resultados. In: ACTAS Congresso Internacional ARTECH, 2006, "Conectando Fronteiras: arte, tecnoloxia, ciencia, sociedade”, Pazo da Cultura, Pontevedra, I 7 e I 8 de novembro de 2006. Vigo: Universidade de Vigo, 2006. p. I75-I 78 .

MATTA-CLARK. Matta-Clark. Catálogo. Madri: Reina Sofia, 2006.

ROBINCON, François. “Le panorama, spetacle de l'histoire”. Le Mouvement social, No. I3I, L'Expression Plastique au XIXe Siecle Regards d'Aujourd'hui (Apr. - Jun, 1985), p. 65-86.

ROUILLÉ, André. La Photographie entre document et art contemporain. Paris: Gallimard, 2005.

\section{ELAINE TEDESCO}

Mestre em Poéticas Visuais e atualmente cursa o Doutorado junto ao Programa de Pós-Graduação em Artes Visuais na Universidade Federal do Rio Grande do Sul. É professora no Centro Universitário Feevale onde coordena o curso de Pós-Graduação Especialização em Poéticas Visuais: Gravura, Fotografia e Imagem Digital. 